\title{
EFFECT OF TAFLA SUPPLEMENTATION ON FEED UTILIZATION, SOME RUMEN PARAMETERS AND NUTRIENT DIGESTIBILITY OF LACTATING COWS.
}

\author{
A.A. Yahia ${ }^{1}$, A. El-Hais ${ }^{1}$ and W.M. Wafa ${ }^{2}$ \\ ${ }^{1}$ Department of Animal Production, Faculty of agriculture, Tanta University, Egypt. \\ ${ }^{2}$ Animal Production Research Institute, Agricultural Research Center, Dokki, Giza, Egypt.
}

(Received 17/10/2018, accepted 6/12/2018)

\section{SUMMARY}

$\mathrm{T}$

he objective of this study was to evaluate the effect of tafla supplementation on feed intake, nutrients digestibility and rumen parameters of lactating cows. Total of 18 Friesian cows (between 2-4 lactations) at late gestation period (30 days prepartum) were used in this study. Cows were divided into 3 similar groups, $(\mathrm{n}=6)$. The 1 group was control (G1), while cows in the $\mathrm{G} 2$ and $\mathrm{G} 3$ groups were supplemented with 100 and $200(\mathrm{~g} / \mathrm{d} / \mathrm{h})$ tafla from 30 days prepartum into 90 days postpartum, respectively. The obtained results showed that, feed intake of CFM and rice straw significantly increase $(\mathrm{P} \leq 0.05)$ by tafla supplementation. Whereas, the average of berseem feed intake did not differ significantly $(\mathrm{P} \leq 0.05)$. There were significantly $(\mathrm{P} \leq 0.05)$ increased in digestibility coefficients of $\mathrm{CP}$ and $\mathrm{CF}$ in $\mathrm{G} 3$ than those in both $\mathrm{G} 1$ and G2. While no significant effects for experimental treatments on digestibility coefficients of DM, OM, EE and NFE. There was no significant effect of dietary tafla supplementation on total digestible nutrients while, it was significantly $(\mathrm{P} \leq 0.05)$ on digestible crud protein, being the higher in $\mathrm{G} 3$ and $\mathrm{G} 2$ than in $\mathrm{G} 1$. Ruminal parameters including $\mathrm{pH}$ value and protozoa count in ruminal liquor (RL) of Friesian cows fed different experimental rations at pre and post $2 \mathrm{~h}$ of feeding did not affected by treatment groups. No significant effect of tafla treatments on rumen liquor NH3-N (mg/100ml), TVFA's (meq/100ml) concentrations. In general, the present results indicated clear improve in rumen function. In conclusion, treatment of lactating cows 30 days prepartum into 150 days postpartum with tafla supplementation at $200(\mathrm{~g} / \mathrm{d} / \mathrm{h})$ recommended to improve feed intake and rumen activity which led to improve lactating cows performanc.

Keywords: cow, tafla, feed intake, rumen parameters and nutrient digestibility.

\section{INTRODUCTION}

In Egypt, Friesian cattle are of great agricultural constituents it is considered the main source for meat and milk production. Tafla is one of the more common feed additives which widely used by commercial dairies in ruminant diets to increase productive and reproductive performances of Friesian cows. Tafla is naturally obtained from some Egyptian mines as a member of clay family which used to improve ruminants performance (Abd EL-Baki et al, 2001 and Salem et al. 2001).

Bentonites as natural clay that comes from volcanic ash used widely in ruminants diets because it can act as gut protectants, it had partiality to binding with aflatoxins in the digestive tract which led to reduce it is absorption into animal organs (Phillips et al., 2002). Also, bentonites reduced the adverse effect of aflatoxins on efficiency and liver function without defects in mineral metabolism (Marroquin-Cardona $e t$ al., 1999). Clay play an important role in animals health, it helps in dispose of cadmium and radiocaesium, virus infection, and parasites that cannot reproduce with clay presence (Grosicki, 2008 and Bellou et al., 2014). Also, clays are extremely used in dairy cattle diets to reduce the transfer of mycotoxins in milk (Bosi et al., 2002).

Positive effects of tafla were reported on steers growth performance (Cho et al., 2001) and daily gain of growing lambs (Salem et al., 2001) and on milk production in buffalo (Saleh et al., 1999) and Friesian 
cows (Mikolaichik and Morozova, 2009). Studies indicated clear improvement in milk composition in ruminant fed diet supplemented with different levels of clay mineral (Garcia Lopez et al., 1988).

In ruminant fed diets containing high level of grain, feed utilization could be high efficiencies with supplementation of sodium bentonite (Sweeney et al., 1980 and Leng, 1986). Dietary supplementation of tafla was found to affect nutrients digestibility (El-Tahan et al., 2005), dry matter intake (Ibrahim, 2012), ruminal parameters (Forouzani et al., 2004), hematological parameters (Nowar et al., 1993) and some blood biochemicals (Mohsen and Tawfik 2002). The haematological and biochemical parameters of rats fed aflatoxin-contaminated diet were improved with the addition of clay, therefore, liver and kidneys histological picture were get better (Abdel-Wahhab et al., 2002).

The objective of this study was to assess the effect of supplementing different levels of tafla as natural clay to dairy cow diet on digestibility coefficient of nutritive values and some rumen parameters.

\section{MATERIALS AND METHODS}

The present study was carried out at the Department of Animal Production, Faculty of Agriculture, Tanta University and Animal production Research Institute, Ministry of Agriculture during the late gestation period (30 days prepartum) of dairy cows in to 3 months postpartum.

This study was conducted to evaluate the effect of feeding two supplementation levels of tafla to Friesian cows during late gestation on digestibility and rumen activity.

\section{Animals:}

A total of 18 Friesian cows (2-4 lactations) at late gestation period (30 days prepartum) were used in this study. Animals were divided randomly into three groups, 6 animals in each.

\section{Treatment groups and feeding system:}

Cows in the 1st group were fed according to NRC (1988) requirements for dairy cows diet was containing of concentrate feed mixture (CFM), berseem (Trifolium alexandrinum) (2nd cut) and rice straw (RS) as a control group (G1). Cows in the 2nd (G2) and 3rd (G3) groups were fed the control ration with tafla clay supplementation 100 and $200(\mathrm{~g} / \mathrm{d} / \mathrm{h})$, respectively.

The contents of CFM were $65 \%$ uncorticated cotton seed cake, $9 \%$ wheat bran, $20 \%$ rice polish, $3 \%$ molasses, $2 \%$ limestone and $1 \% \mathrm{NaCl}$. Different feedstuffs chemical composition (on dry matter basis, \%) was presented in Table (1). Feeding period lasted from approximately 30 days prepartum to 90 days postpartum.

Table (1): Chemical composition of different feedstuffs used in feeding experimental cows

\begin{tabular}{lccccccc}
\hline \multirow{2}{*}{ Item } & DM \% & \multicolumn{5}{c}{ Chemical analysis on DM basis (\%) } \\
\cline { 3 - 8 } & & OM & CP & CF & EE & NFE & ASH \\
\hline CFM & 90.63 & 90.35 & 17.04 & 9.21 & 3.01 & 61.09 & 9.65 \\
Rice straw (RS) & 92.14 & 82.71 & 4.29 & 34.13 & 0.93 & 43.36 & 17.29 \\
Berseem forage (BF) & 13.62 & 86.03 & 17.54 & 24.12 & 2.29 & 42.08 & 13.97 \\
Tafla clay & 92.91 & 7.03 & - & 7.03 & - & - & 92.97 \\
\hline $\begin{array}{l}\text { DM: Dry matter, OM: Organic matter, CP: Crude protein, CF: Crude fiber EE: Ether extract, NFE: Nitrogen free } \\
\text { extract, CFM: Concentrate feed mixture }\end{array}$
\end{tabular}

\section{Digestibility trails:}

Digestibility trails were conducted at 60 days postpartum using three cows from each group. Acid Insoluble Ash (AIA) method was used for nutrients digestion coefficients based on use the silica as indigenous marker (Van Keulen and Young, 1977) according to the following formula: 
Digestion coefficient $(\%)=100-\left[\begin{array}{cc}\frac{\% \text { indicator in feed }}{\% \text { nutrient in feces }} \\ \% \text { indicator in feces }\end{array} \quad \times 100\right]$

Feces were collected from cow's rectum during 3 consecutive days in the morning before feeding and at evening. After the end of the collection period, representative samples were taken from feces of each cow and dried for 48 hours at $60^{\circ} \mathrm{C}$. Samples of faces were grinded to pass through a $0.5 \mathrm{~mm}$ screen and kept until chemical analysis in close tightly plastic containers.

Samples of CFM, BF, RS and feces were taken and prepared for the chemical analysis for crude protein (CP), crude fiber (CF), ether extract (EE) and ash according to the methods of A.O.A.C. (1995).

\section{Rumen parameters:}

After 120 days postpartum, rumen liquor (RL) samples were collected individually from three animals in each group for three consecutive days, just before morning feeding and 2 hours post feeding, by using stomach tube, about $200 \mathrm{ml}$ of RL were collected from each animal and strained through four layers of cheese cloth and acidity was immediately determined by the pH meter (Apera ${ }^{\circledR}$ Instruments AI209 PH20) after preparing RL.

According to micro diffusion method (Conway and O'Malley, 1942), the concentration of ammonia-N in RL was determined, while total concentration of volatile fatty acids (TVFA's) were determine by distillation according to Abou-Akkada and El-Shazly (1964). The protozoal cells count in RL was performed by microscopic examination according to Collins and Lyne (1985).

\section{Statistical analysis:}

Data were statistically analyzed using analysis program version 15 of SPSS (2010). The significant differences for group or sampling time were performed by multiple range test (Duncan, 1955). The model used was as following:-

$$
\begin{aligned}
& \quad \mathrm{Yij}=\mu+\mathrm{Gi}+\mathrm{Eij} \\
& \text { Where:- } \mathrm{Yij}=\text { Observations, } \mu=\text { General mean, } \mathrm{Gi}=\text { Treatment effect and } \mathrm{Eij}=\text { Error }
\end{aligned}
$$

\section{RESULTS AND DISCUSSION}

\section{Feed intake and feeding value:}

Means and standard errors of feeding value of cows in different treatment groups are presented in Table (2).

Results showed that feed intake of CFM significantly increase ( $\mathrm{P} \leq 0.05)$ in $\mathrm{G} 3$ compared to G1 by the percentage of $30 \%$. Also, there was significant increase in rice straw intake in G3 compared with G1 by $39.2 \%$ and in $\mathrm{G} 2$ by $30.5 \%$, in the same order. Whereas, the average of berseem feed intake did not differ significantly $(\mathrm{P} \leq 0.05)$. It is worth to noting that, the increase in cows feed intake was reflect the effect of tafla supplementation on improve animal nutritive value appetite. In this respect, Forouzani et al. (2004) showed feeding lambs on diet supplemented with clay elements led to significantly increased in daily dry matter intake. Also, El-Tahan et al. (2005) fed growing calves on diet supplemented with tafla they showed that tafla addition improved dry matter intake. Recently, Ghaemnia et al. (2010) and Ibrahim (2012) indicated significant increase in dry matter intake in lambs fed rations supplemented with clay element. While, Yazdani et al. (2009) in crossbred steers and Norouzian et al. (2010) on lambs, found no effect for clay elements on daily dry matter intake. In dairy cows fed diet supplemented with natural clay elements, Moate et al. (1985) and Johnson et al. (1988) indicated significant decreased in feed intake.

Results showed that the effect of dietary tafla supplementation (Table 2) on total digestible nutrients (TDN \%) was not significant, while, the effect of tafla treatment was significantly $(\mathrm{P} \leq 0.05)$ on digestible crud protein (DCP \%) in G3 than those in G1 or G2. However, the differences between G2 and G3 were not significant. On the other hand, there were insignificant differences of nutritive values as total 
digestible nutrients (TDN \%). It was higher in cows of G3 and G2 than those in G1, respectively (Table 2).

The significant improvement in nutritive values as DCP was associated with increasing the digestibility coefficients of $\mathrm{CP}$. The observed improvement in TDN was related to the increase in digestion of $\mathrm{OM}, \mathrm{EE}$ and $\mathrm{CF}$ was insignificant.

In accordance with the present results, Salem et al. (2001) and Hassan (2009) showed that no significant differences were observed in the nutritive value as TDN. While Salem et al. (2001) indicated a significant increase in DCP.

In general, the nutritive values improvement as TDN and DCP reflect the beneficial effects of dietary supplementation with $200 \mathrm{~g}$ tafla/h/d on digestibility coefficients of most nutrients as compared with the control diet.

\section{Digestibility coefficients and nutrient values:}

The nutrients digestibility coefficients of different rations are presented in Table (2). Data reflected that digestion coefficient of $\mathrm{CP}$ and $\mathrm{CF}$ were affected significantly be tafla treatment.

Table (2): Means and standard errors of daily feed intake, nutrients digestibility and nutritive values $(\%)$ of cows as affected by different experimental treatments:-

\begin{tabular}{|c|c|c|c|}
\hline \multirow{2}{*}{ Feed intake $(\mathrm{kg} / \mathrm{h} / \mathrm{d})$} & \multicolumn{3}{|c|}{ Experimental group } \\
\hline & G1 & $\mathrm{G} 2$ & G3 \\
\hline CFM & $5.00 \pm 0.29^{b}$ & $5.33 \pm 0.33^{b}$ & $6.50 \pm 0.28^{\mathrm{a}}$ \\
\hline Berseem $2^{\text {nd }}$ cut & $17.33 \pm 1.45$ & $18.33 \pm 1.20$ & $19.67 \pm 0.33$ \\
\hline Rice straw & $3.83 \pm 0.44^{\mathrm{b}}$ & $5.00 \pm 0.29^{\mathrm{ab}}$ & $5.33 \pm 0.33^{\mathrm{a}}$ \\
\hline \multicolumn{4}{|c|}{ Nutrients digestibility: } \\
\hline $\mathrm{DM}$ & $63.78 \pm 4.31$ & $69.41 \pm 0.94$ & $72.05 \pm 1.00$ \\
\hline OM & $67.98 \pm 3.76$ & $70.79 \pm 0.49$ & $72.76 \pm 1.38$ \\
\hline $\mathrm{CP}$ & $61.08 \pm 3.74^{b}$ & $68.82 \pm 0.92^{\mathrm{ab}}$ & $72.85 \pm 1.56^{\mathrm{a}}$ \\
\hline $\mathrm{EE}$ & $61.74 \pm 4.66$ & $65.48 \pm 1.07$ & $67.84 \pm 1.46$ \\
\hline $\mathrm{CF}$ & $52.56 \pm 4.29^{b}$ & $62.97 \pm 1.93^{\mathrm{ab}}$ & $65.04 \pm 2.62^{\mathrm{a}}$ \\
\hline NFE & $68.61 \pm 4.46$ & $71.29 \pm 0.46$ & $75.32 \pm 1.10$ \\
\hline \multicolumn{4}{|l|}{ Nutrient values: } \\
\hline TDN & $58.08 \pm 3.93$ & $63.14 \pm 0.81$ & $65.79 \pm 0.90$ \\
\hline DCP & $7.81 \pm 0.48^{\mathrm{b}}$ & $8.85 \pm 0.12^{\mathrm{ab}}$ & $9.34 \pm 0.20^{\mathrm{a}}$ \\
\hline
\end{tabular}

- G1 = Control, G2= Control $+100(\mathrm{~g} / \mathrm{h} / \mathrm{d})$ with tafla clay supplementation, G3= control+ $200(\mathrm{~g} / \mathrm{h} / \mathrm{d})$ with tafla clay supplementation

- Means with different superscripts $(a, b)$ within the same row are differ significantly at $(P \leq 0.05)$.

in ruminal NH3-N concentration post-feeding lamb on diet supplemented with zeolitea. The results in table $(2)$ showed significantly $(\mathrm{P} \leq 0.05)$ increased in digestibility coefficients of $\mathrm{CP}$ and $\mathrm{CF}$ in G3 than those in both G1 and G2 (72.85 vs. 61.08 and $68.82 \%$ for $\mathrm{CP}$ and 65.04 vs. 52.56 and $62.97 \%$ for $\mathrm{CF})$. While the differences in digestion coefficient of CP and CF was not significant between G1 and G2 and G2 versus G3 group. The results presented in Table (2), showed that digestibility of DM, OM, EE and NFE significantly $(\mathrm{P} \leq 0.05)$ for cows fed tafla supplemented rations than those in control diet.

In agreement with the present results, Salem et al. (2001) found that diets supplemented with 4 or $8 \%$ bentonite had higher $(\mathrm{P} \leq 0.05)$ digestibility value of $\mathrm{CP}$ and $\mathrm{CF}$ than those fed un-supplemented diets. Also, Mikolaichik and Morozova (2009) found marked improvement in digestibility coefficients crude protein of dairy cows supplemented with bentonite. Whereas, Grabherr et al. (2009) fed dairy cows on 
diet supplemented with10 and $20 \mathrm{~g}$ zeolite $/ \mathrm{kg}$ of dry matter they indicated significant reduced in ruminal dry matter.

On the other hand, Cole et al. (2007) reported that supplementing diets of beef steers with zeolite did not affect CP digestibility. Also, Aguilera-Soto et al. (2009) indicated that adding sodium bentonite to Holstein cow diets had no effect on digestibility of different nutrients among experimental treatments.

\section{Rumen parameters:}

Values of some ruminal parameters as means including $\mathrm{pH}$ value, NH3-N concentration, TVFA's and protozoa count in ruminal liquor (RL) of Friesian cows fed different experimental rations at pre and post $2 \mathrm{~h}$ of feeding are presented in Table (3).

Current experiment showed that overall mean affected by treatments at different sampling time, being the highest value $(\mathrm{P} \leq 0.05)$ in control group (6.11) and the lowest at G3 (5.81). While, the effect of sampling time on overall mean of $\mathrm{pH}$ value was significant $(\mathrm{P} \leq 0.05)$, being lower at 2 hours post-feeding (5.72) than pre-feeding value (6.16). The effect of interaction of treatment groups with sampling time was insignificant which reflect the lower $\mathrm{pH}$ values in tafla group (G2 and G3) than those of control (G1). In good agreement with the present results, similar trend was found by Ahmed (1999) who reported significant decrease in ruminal $\mathrm{pH}$ of lactating goats fed on diet supplemented with $3 \%$ tafla. On the other hand, Grabherr et al. (2009) reported that the ruminal $\mathrm{pH}$ value not affected by adding zeolite to dairy cows.

Table (3): Means and standard errors of cows rumen liquor parameters as affected by different experimental treatments

\begin{tabular}{|c|c|c|c|c|}
\hline \multirow{2}{*}{ Sampling time } & \multicolumn{3}{|c|}{ Experimental group } & \multirow{2}{*}{ Overall mean } \\
\hline & G1 & $\mathrm{G} 2$ & G3 & \\
\hline \multicolumn{5}{|l|}{$\mathrm{pH}$ - value } \\
\hline 0 & $6.28 \pm 0.11$ & $6.08 \pm 0.11$ & $6.14 \pm 0.09$ & $6.16 \pm 0.06^{\mathrm{a}}$ \\
\hline 2 & $5.95 \pm 0.12$ & $5.71 \pm 0.23$ & $5.49 \pm 0.10$ & $5.72 \pm 0.09^{\mathrm{b}}$ \\
\hline Overall mean & $6.12 \pm 0.10^{\mathrm{a}}$ & $5.90 \pm 0.27^{\mathrm{ab}}$ & $5.82 \pm 0.16^{\mathrm{b}}$ & $5.94 \pm 0.08$ \\
\hline \multicolumn{5}{|c|}{$\mathrm{NH}_{3}-\mathrm{N}(\mathrm{mg} / 100 \mathrm{ml})$} \\
\hline 0 & $18.38 \pm 1.07$ & $17.73 \pm 0.98$ & $17.16 \pm 1.00$ & $17.76 \pm 0.54^{\mathrm{b}}$ \\
\hline 2 & $22.57 \pm 0.99$ & $21.90 \pm 0.33$ & $22.21 \pm 0.38$ & $22.23 \pm 0.33^{\mathrm{a}}$ \\
\hline Overall mean & $20.48 \pm 1.14$ & $19.82 \pm 1.04$ & $19.69 \pm 1.23$ & $19.99 \pm 0.62$ \\
\hline \multicolumn{5}{|c|}{ TVFA's (meq/100ml) } \\
\hline 0 & $5.90 \pm 1.00$ & $6.18 \pm 1.45$ & $6.03 \pm 0.84$ & $6.04 \pm 0.57^{\mathrm{b}}$ \\
\hline 2 & $9.77 \pm 1.48$ & $10.37 \pm 1.96$ & $11.15 \pm 1.75$ & $10.43 \pm 0.89^{\mathrm{a}}$ \\
\hline Overall mean & $7.84 \pm 1.18$ & $8.28 \pm 1.44$ & $8.59 \pm 1.43$ & $8.24 \pm 0.74$ \\
\hline $\begin{array}{l}\text { Protozoal count } \\
\left(\times 10^{3} / \mathrm{mm}^{3}\right)\end{array}$ & $238.67 \pm 23.75^{\mathrm{c}}$ & $319.33 \pm 22.30^{\mathrm{b}}$ & $389.67 \pm 6.36^{\mathrm{a}}$ & $315.89 \pm 23.82$ \\
\hline $\begin{array}{l}\mathrm{S} 1=\text { Control, } G 2=\mathrm{C} \\
\text { upplementation }\end{array}$ & trol+100 $(\mathrm{g} / \mathrm{h} / \mathrm{d}) \mathrm{wi}$ & fla clay supplementat & $33=$ control +200 & l) with tafla clay \\
\hline
\end{tabular}

Data in the present study of ruminal $\mathrm{pH}$, being around the normal range (5.5-7.0) which were identified value as critical maintaining the ruminal fiber digestion (Hungate, 1966; Garrett, 2000 and Bravo and Wall, 2016). Also, clays showed marked alkalinizing capacity and have ability for H+ exchange at different $\mathrm{pH}$ ranges (Yong et al., 1990).

The obtained results indicated that no significant effect for dietary treatment was noticed for ammonia and total volatile fatty acids concentrations in rumen liquor. While, sampling times had significant effect on NH3-N concentration at $(\mathrm{P} \leq 0.05)$, being higher post-feeding compared to pre-feeding $(22.23$ vs. 17.76 $\mathrm{mg} / 100 \mathrm{ml})$. There were insignificant effect for interaction between treatment groups and sampling time on NH3-N concentration, being high post-feeding compared with pre-feeding. Similar trend was found in dairy cows, Dschaak et al. (2010) indicated that no significant effect was found in ruminal NH3-N concentration by adding zeolite to diet. Also, Aguilera-Soto et al. (2009) demonstrated that ammonia 
concentration in rumen fluid did not differ $(\mathrm{P} \leq 0.05)$ among dietary treatments with or without $1 \%$ sodium bentonite. On the other hand, Forouzani et al. (2004) indicated significant increase

Data of TVFAs concentration had no significant effect by tafla treatments being low in control group $(7.83 \mathrm{meq} / 100 \mathrm{ml})$. However, it was affected significantly $(\mathrm{P} \leq 0.05)$ by sampling time, being high postfeeding $(10.43 \mathrm{meq} / 100 \mathrm{ml})$ compared with pre-feeding $(6.04 \mathrm{meq} / 100 \mathrm{ml})$. The interaction effect between treatment groups and sampling time did not affect significantly. In this respect, Bosi et al. (2002) found significant reduction in VFA concentration of dairy cattle rumen liquor when it fed on diet with $200 \mathrm{~g}$ clinoptilolite addition. Also, Dschaak et al. (2010) indicated that, no significant effect for zeolite supplementation on NH3-N concentration in ruminal liquor of dairy cows. On the other hand, Ibrahim (2012) found that the ruminal total volatile fatty acids significantly increased in rams feed diet with tafla addition. Also, Ahmed (1999) showed significant increase in ruminal total volatile fatty acids when goats fed diet with $3 \%$ tafla supplementation.

Data showed that there is a significant $(\mathrm{P} \leq 0.05)$ effect for treatment groups on protozoal count. It was significantly $(\mathrm{P} \leq 0.05)$ increased in $\mathrm{G} 3$ by $163.3 \%$ and by $133.8 \%$ in $\mathrm{G} 2$ as compared to G1. Also, the differences between $\mathrm{G} 2$ and G3 were significant $(\mathrm{P} \leq 0.05)$ being high in $\mathrm{G} 3(389.67 \mathrm{cell} / \mathrm{mm} 3)$ compared to G2 (319.33 cell/mm3). These results are in harmony with the findings of several authors, who found that the supplementation of diet with clay had a significant effect on increasing protozoal count in rumen liquor (Nistiar et al., 2000, Krause and Oetzel, 2005 and Weimer et al., 2010). In this respect, Ibrahim (2012) indicated that the inclusion of clay elements in ruminant diet had beneficent effect on rumen microorganisms by release the ions in rumen liquor gradually which led to increase it populations.

\section{REFERENCES}

A.O.A.C. (1995). Official Methods of Analysis 15th Ed. Association of Official Analytical Chemists. Arlington, VA, USA.

Abd El-Baki, M.S.; S.M. Bassuny; A.M. Aiad and E.M. Hassona (2001). Clays in animal nutrition.9. Invitro adsorption of ammonia by some local clays and using tafla clay in pelleted complete feed containing urea for sheep. Egyptian J. Nutr. and Feeds, 4 (special issue) : 77-87.

Abdel-Wahhab, M.A.; S.A. Nada and F.A. Khalil (2002). Physiological and toxicological responses in rats fed aflatoxin-contaminated diet with or without sorbent materials. Anim. Feed Sci. Techn. 97: 209-219.

Abou-Akkada, A. R. and K. El-Shazly (1964). Effect of absence of ciliate protozoa from the rumen on microbial activity and growth of lambs. Appl. Micorbial, 12: (384).

Aguilera-Soto, J.I.; R.G. Ramirez; C.F. Arechiga; M.L. lorente; M.A. Lopez-Carlos; J.A. Pina-Flores; C.A. Medina-flores; H. Rodriguez Frausto; D. Rodriguez-Tenorio and H. Gutierrez-Banuelos (2009). Effect of feed additives on digestibility and performance of Holstein cows fed wet brewers grains. J. Appl. Anim. Res., 36: 227-230.

Ahmed, M.E. (1999). Improving feed conversion efficiency during reproduction stress-phases. Ph.D. Thesis, Fac. of Agric. Mansoura University, Egypt.

Bellou, M.; V. Syngouna; S. Paparrodopoulos; A. Vantarakis and C. Chrysikopoulos (2014). The impact of dynamic clay system on the infectious viruses. European Congress of Clinical Microbiology and Infectious Diseases, Barcelona, Spain, 10 - 13 May 2014.

Bosi. P.; D. Creston and L. Casini (2002). Production performance of dairy cows after the dietary addition of clinoptilolite. Ital. J Anim. Sci., 1:187-195.

Bravo, D. M. and E. H. Wall (2016). The rumen and beyond: Nutritional physiology of the modern dairy cow. J. Dairy Sci. 99:4939-4940.

Cho, W.M; B.H. Paek, S.W. Kang, J.S. Kim, Y.K. Kim (2001). Effects of dietary supplements of clay minerals on the growth performance and immunity in growing Hanwoo steers. Journal of Animal Science and Technology. 43: 2, 203-210.

Cole, N.A.; R.W. Todd and D.B. Parker (2007). Use of fat and zeolite to reduce ammonia emissions from beef cattle feed yardes.Int.Symp. Air Quality Waste Mgt. Agric., Broomfield, CO. 
Collins, C.H. and P.M. Lyne (1985). Microbiological methods. 5th Ed. Butterworths, London, 167181.pp.

Conway, E. J. and E. O'Malley (1942). Micro diffusion method: Ammonia and urea using buffered absorbents (revised methods of ranges greater than 10mg N). Biochem. J. 36: (655-661).

Dschaak, C.M.; J.S. Eun; A.J. Young; R.D. Stott and S. Peterson (2010). Effects of Supplementation of Natural Zeolite on Intake, Digestion, Ruminal Fermentation and Lactational Performance of Dairy Cows. The Professional Animal Scientist, 26: 647-654.

Duncan, D. B. (1955). Multiple range and multiple F test. Biometrics, 11: (1-42).

El-Tahan, A.A.H.; R. I. Moawd; A.A. Zaki and M. Marghany (2005). Effect of adding tafla clay on perfromance of growing calves fed rations containing maize silage. Egypt. J. Nutr. and Feeds .8(1) Special Issue :(167-178).)

Forouzani, R; E. Rowghani and M.J. Zamiri (2004). The effect of zeolite on digestibility and feedlot performance of Mehraban male lambs given a diet containing ureatreated maize silage. Animal Science. 78:1, 179-184.

Garcia Lopez, R.; A. Elias; J.P. de la Paz; G. Gonzalez (1988). The utilization of zeolite by dairy cows. 1. The effect on milk composition. Cuban, J. Agric.Sci. 22: 22-33.

Garrett, J. (2000): Use yeast culture to feed the rumen first. Diamond V Technical Center, Ceder Rapids, Iowa USA. Yeast culture laboratory research report. Feed Management, July-August 2000

Ghaemnia, L; M. Bojarpour, K. Mirzadeh, M. Chaji and M. Eslami (2010). Effects of different levels of zeoliteon digestibility and some blood parameters in Arabic lambs. Journal of Animal and Veterinary Advances, 9: 779-781

Grabherr, H.; M. Spolders; M. Furll and G. Flachowsky (2009). Effect of several doses of zeolite A on feed intake, energy metabolism and on mineral metabolism in dairy cows around calving. Journal of Animal Physiology and Animal Nutrition. 93: 2, 221-236

Grosicki, A. (2008). Bentonite influence on manganese uptake in rats. Bull Vet Inst Pulawy 52, 441-444.

Hassan, E.H.S (2009). Utilization of growth promoters and bentonite in sheep rations. Ph.D. Thesis, Faculty of Agriculture Al-Azhar University.

Hungate, R.E. (1966): The rumen and its microbes. Academic Press., New York and London.

Ibrahim, A.K. (2012). Effect of clay mineral on utilization of some mineral elements in ruminant feeding. PhD. Thiesis, Fac. of Agric., Zagazig University

Johnson, M. A.; T.F. Sweeney and L.D. Muller (1988). Effect of feeding synthetic zeolite and sodium bicarbonate on milk production, nutrient digestion and rate of digest passage in dairy cows. J. Dairy Sci., 71(4): 946-953.

Krause, K.M., and G.R. Oetzel. (2005). Inducing subacute ruminal acidosis in lactating dairy cows. J. Dairy Sci. 88: 3633-3639.

Leng, R.A. (1986). Drought - feeding strategies - Theory and Practicen, Pernamble Books: Ar midale.

Marroquin-Cardona, A.; Y. Deng; J. Taylor; C. Hallmark; N. Johnson and T. Phillips. (2009). In vitro and in vivo characterization of mycotoxin-binding additives used for animal feeds in Mexico. Food Addit. Contam. A 26: 733- 743.

Mikolaichik, I.N. and L.A. Morozova (2009). Biological basis of using bentonite-based mineral-vitamin premix when increasing the milk yield of cows. Russian Agricultural Sciences. 35: 3, 199-201.

Moate P.J.; G.L. Rogers and T. Clarke (1985). Effect of bentonite on re productivity of dairy cows fed a pasture diet. Proceeding of a symposium at the University of New England, Paper No. 15, University of New England Publishing Unit, Armidale, Australia.

Mohsen, M. K. and E.S. Tawfik (2002). Growth perfromance, rumen ermentation and blood constituents of goats fed diets supplemented with bentonite. (Kafr El-Sheikh) Fac. of Agric.Tanta Univ.

Nistiar, F., J. Mojzis; G. Kovac; H. Seidel; O. Racz (2000). Influence of intoxication with organophosphates on rumen bacteria and rumen protozoa and protective effect of clinoptilolite-rich zeolite on bacterial and protozoan concentration in rumen. Folia Microb. 45: 567-571. 
Norouzian, M.A; R. Valizadeh; A.A. Khadem; A. Afzalzadeh and A. Nabipour (2010). The effects of feeding clinoptilolite on hematology, performance, and health of newborn lambs. Biological Trace Element Research. 137: 2, 168-176

Nowar, M.S.; K. Al-Shawabkeh and H.N. Khour (1993). Effect of feeding farm animals with Jordanian clay deposites containing montmorillonite. 1-Effect of fatting lambs' performance, with special reference to blood hematology, liver and kidney functions, and parasitological and serological examinations. Zagazig J.Agric.Res.Vol 20, No.2A, 651-667.

NRC, National Research Council (1988). Nutrient requirements of dairy cattle 6th Rev. Ed., National Academy Press, Washington, D.C.

Phillips T.D.; S.L. Lemke and P.G. Grant (2002). Charakterization of clay-based enterosorbents for prevention of aflatoxicosis. Adv. Exp. Med. Biol., 504, 157-171.

Saleh, M.S; E.M Abel-Raouf; M.K. Mohsen and A.Y. Salem (1999). Bentonite supplementation to concentrate ration for lactating buffaloes. Animal Prod. Dept., Fac. Of Agric. Kafr El-Sheikh, Tanta Univ., Egypt. Egyptian-Journal-of-Nutrition-and-Feeds. 2(Special Issue): 67-78.

Salem, F.A.F.; Hanaa El-Amary and S.H. Hassanin (2001). Effect of bentonite supplementation on nutrients digestibility, rumen fermentation, some blood physiological parameters and performance of growing lambs. Egypt .J .of Nutr. and Feeds.4(special Issue: (179-191.).

SPSS Copyright ${ }^{\circledR}$ SPSS Inc. (2010): Version 15.

Sweeney, T. F., L.S. Bull and R.W. Hemken (1980). Effect of zeolite as a feed additive on growth performance in ruminants .J. Anim. Sci. 51 (Suppl.1): 401.

Van Keulen, J.M.H. and B.A. Young (1977). Evaluation of acid-insoluble as a natural marker in ruminant digestibility studies. J. Anim. Sci. 44: (2).

Weimer, P.J., D.M. Stevenson, and D.R. Mertens. (2010). Shifts in bacterial community composition in the rumen of lactating dairy cows under milk fat-depressing conditions. J. Dairy Sci. 93: 265-278.

Yazdani, A.R; D. Hajilari and M.H. Ghorbani (2009). Effect of clinoptilolite zeolite on feedlot performance and carcass characteristics in Holstein steers. Indian Journal of Animal Research. 43, (4): 300-303.

Yong, R. N.; D. P. Warkentin; Y. Phadungchewit and R. Galvez (1990). Buffer capacity and lead retention in some clay materials. Water Air Soil Pollut. 53:53-67.

\section{تأثير إضافة الطفلة على الاستفادة من الغذاء وبعض قياسات الكرش وهضم المكونات الغذائية للأبقار الحلابة.}

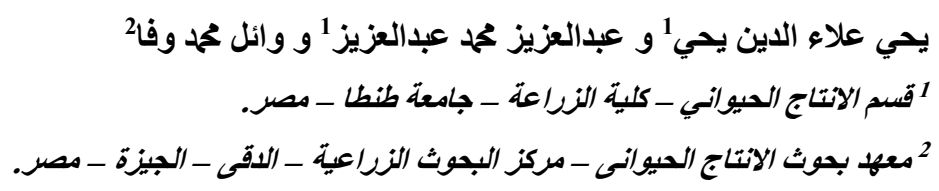

الهدف من هذة الدر اسة هو تقييم إضافة الطفلة على الاستفادة من الغذاء وبعض خصائل فئص الكرش و هضم المكونات الغذائية في الأبقار

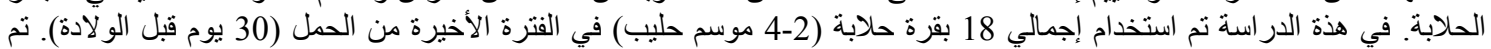

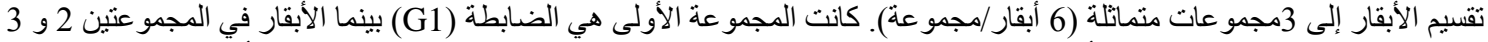

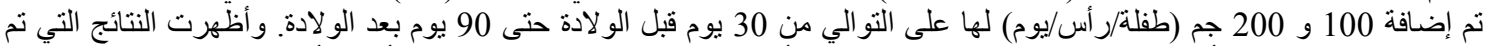

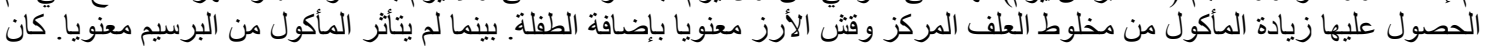

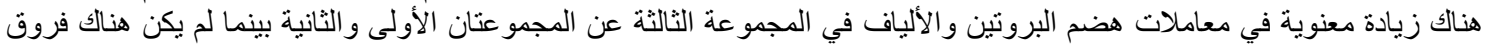

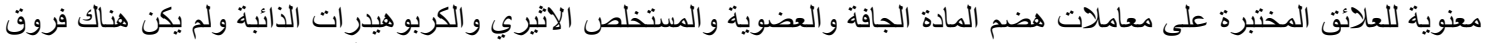

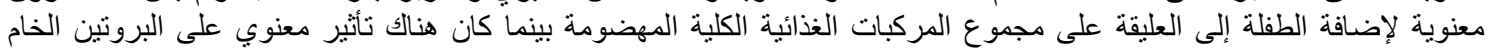

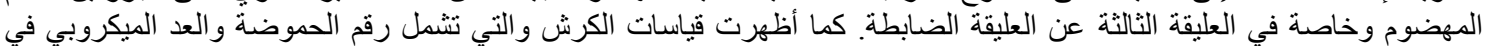

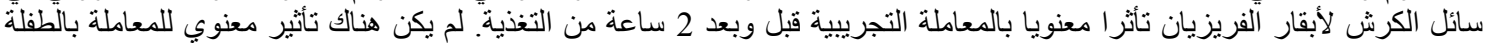

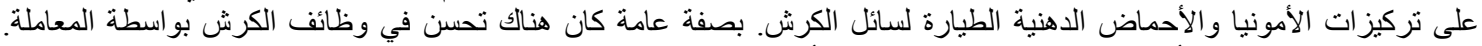

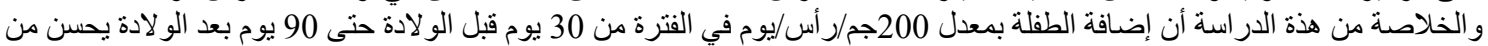
المأكول ومعاملات الهضم ووظة الأنة إنف الكرش للأبقار الحلابة. 